\title{
THE IMPORTANCE OF INTERNAL DIRECTIVES OF THE UNIVERSITY FOR THE INTELLECTUAL PROPERTY PROTECTION
}

\author{
Andrea Črojová ${ }^{1}$, Jana Jarošová ${ }^{2}$
}

\begin{abstract}
In this paper, we investigate the management system for intellectual property (IP) within the Center for Technology Transfer (CTT) currently operating in the University Science Park-organizational unit of the University of Žilina. The CTT deals with procedural issues: acquisition of intellectual property rights, IP protection, and IP commercialization. In solving selected issues involving the Internal Directive's content regulating the IP protection and commercialization in CTT of the University of Žilina, we are using available information and knowledge of the directives from both domestic and international universities.

This investigation helps the CTT in formulating more effective directive contents for University Science Park in Žilina. The entire system of research and development funding through projects requires accurate and complex monitoring of the use of allocated funds for various activities and persons. For internal usage, it is necessary to obtain discreet evidence that would allow accurate identification of funding received directly from IP creationrelated projects.
\end{abstract}

JEL Classification Numbers: I25, M41, O3, DOI: http://dx.doi.org/10.12955/cbup.v2.458

Keywords: commercialization, copyright, intellectual property, higher education, internal directives, patent protection, technology transfer, university.

\section{Introduction}

According to ZVS (2002), the role of higher education institutions, which are a part of the European Higher Education Area and the European Research Area, is to develop harmonious personality, knowledge, wisdom, grace and creativity in man. They must also contribute to the development of education, science, culture and health for the welfare of the whole society-thereby contributing to the development of a knowledge society. Fulfilling this mission is the core activity of universities. As Bíla (2010) reported, for overall economic development, increasing economic competitiveness and quality of life the role of human capital accumulation, results of research, and development and innovation support are the crucial attributes.

This fact is confirmed by various economic theories and empirical research. We are focusing on research and development as one of the basic tasks of universities. ZVS (2002) directly stated, in Article (11), that Higher Education Institutions are artificial entities engaged in research and development and, in Article (12), that the role of Higher Education Institutions in science and technology is to conduct fundamental research, applied research and development, use the latest knowledge of science and technology in the education of students, and involve them in creative research activity.

According to Griliches (1994), investment in education, science, research and innovation brings its effects with a time delay but with a significant contribution to society. However, if research results are not properly utilized and disseminated, the increase in the universities research volume itself will not lead to an optimal impact on the country's competitiveness. Markman, Gianiodis, Phan, \& Balkin (2005) found that the "faster" CTTs can commercialize technologies that are protected under patents, resulting in greater financial returns to the university. However, an innovative idea may be worthless if its inventor is unable to successfully commercialize it in the competitive market. For this purpose, the CTT of the University of Žilina is formed in order to establish an institutional background for the cooperation between university and businesses. One of the main tasks of CTT at present is to create documentation in the form of directives, manuals, contracts, methodological guidelines to ensure the intellectual property management at all stages in accordance with other internal processes of the

\footnotetext{
${ }^{1}$ Andrea Čorejová, University Science Park, University of Žilina, Slovakia, andrea.corejova@uvp.uniza.sk

2 Jana Jarošová, University Science Park, University of Žilina, Slovakia, jana.jarosova@uvp.uniza.sk.
} 
university. Siegel, Waldman, \& Link (2003) concluded that intellectual property policies and organizational practices could potentially enhance technology transfer effectiveness.

In this paper, we investigate the management system of intellectual property (IP) of universities, which is a result of their research and development activities. The whole process of IP protection and commercialization should be incorporated into the internal directives of the University and create a platform for an efficient university knowledge transfer into practice. With regard to relevance and extensity, we will try to outline the basic problems we need to solve within the CTT at the University of Žilina.

\section{Methodology}

In resolving selected issues of the internal guideline's content regulating the intellectual property protection and commercialization in CTT at the University of Žilina, we use available information and knowledge of the directives from other universities in our country and abroad. In the first step, we focus on an institutional support to provide CTT at most universities. It is essential for us to understand the position of CTT relative to its parent institution. Using the comparative analysis, we have identified the key points that are common to most Internal Directives involving intellectual property in similar institutions, such as the University of Žilina. Secondary research is based on publications of Brighton (2012), Bílá (2010), and Slovak Center of Scientific and Technical Information [CVTI] (2011).

The result is the systematization of knowledge contained in the internal directives of universities, which represents the basis for the formulation of internal directives at the University of Žilina in the intellectual property area.

\section{Problems in using Intellectual Property results in Higher Education Institutions}

In many cases, universities are not interested and do not realize the potential benefits associated with IP commercialization. One of the limitations for a successful business activity is a dysfunctional IP management system. In the analysis, we use the survey "Exploitation of intellectual property at universities" (Babiaková, 2010), which was performed by the method of interview using a questionnaire in public universities in Slovakia and in selected European Union countries, i.e. Czech Republic, Poland, Hungary, Lithuania, Latvia, and Germany. The survey shows that most respondents use the results of intellectual property in publication activity, scientific research, and education. Less than a half use their results in faculty development, business activities or in the work organization at the faculty, even though legislation in this regard is sufficient and entitles universities to conduct a business. Nevertheless, the analysis research has shown that intellectual property is commercialized in less than the half of surveyed higher education institutions.

\section{Institutional promotion of the university knowledge transfer into practice in Slovakia and other countries}

Universities, in principle, do not have sufficient financial resources required to conduct research and development. Necessary financial resources are derived from project funding or research contracts with commercial partners. Therefore, current university structures in the Slovak Republic are focusing on building up Technology Transfer Centers or Centers for Knowledge Transfer to ensure that commercial application of university knowledge and research results are put into practice. This activity corresponds to the commercialization of IP management system abroad.

In some cases, the centers are formed as a part of the universities structures, while elsewhere they are created separately as specialized business entities in which the university shares part-ownership 
through agreements. Thus, only through this organization is the sole mean of IP commercialization for the university. These centers should allow for complexity, flexibility, faster decisions, feedback control, and management of the universities IP management. However, the CTT of the University of Žilina is built as part of the university structures—not as a separate entity.

Currently, universities and public research organizations in the United States operate more than 200 CTT's. Internal directives of their parent organization, which dictates the procedures for patenting, licensing, copyright management, etc., mostly manage them. Scientists are also motivated to commercialize their results for financial benefits. In the United Kingdom, universities are required to protect intellectual property, if there is a chance for commercial exploitation. On the basis of internal directives and regulations, the profits from the commercialization are divided between researchers, faculty and the university. In Germany, except of the university research, research organizations work with the idea of improving the transfer of knowledge into practice and commercializing results of their own research. In addition, CTT's at universities in the Czech Republic have been established only in recent years. Despite the fact that the first CTT was founded in 1991, other universities only began creating such centers, supported by the Structural Funds, after 2004. Unlike the U.S., UK and Germany, CTT's in the Czech Republic are either a separate part of the university or a rector's office. Similar to Czech Republic, CTT's at universities in Latvia have started establishing in recent years. In 2005, the Ministry of Economy moved toward a program that promotes the creation of these Centers at universities. It has generated CTT practically at every Latvian University. On the basis of the Latvian legislation, CTT is defined as a structural unit of a university or research organization that promotes technology and knowledge transfer, and is responsible for establishing and maintaining contacts with business.

CTT's in all of the aforementioned countries focus mainly on transferring technology, assessing research potential, strengthening scientific competency, finding partners for cooperation, organizing conferences, promoting science, and marketing and development of regional and international networks.

\section{University policies on Intellectual Property and Internal Directives}

This section entails a comparative analysis of selected universities directives in Slovakia and abroad, including University of Oxford, Cambridge University, Bournemouth University, Masaryk University in Brno, Brno University of Technology, and Slovak University of Technology in Bratislava. For the purpose of the article, the secondary research is also conducted using the results of surveys from Brighton (2012) and CVTI (2011).

All of the aforementioned institutions have directives related to intellectual property, which emphasize the right to intellectual property created by employees as a result of their work at the university or institution, or through the use institution resources. The institute has the priority to decide whether to utilize the intellectual property or return it to the originator. British universities have the articles in the directives linking to employment contracts. Universities can also lay claims to the copyright resulting from work derived from hardware and software they own. This applies to particular computer programs, databases, and analyses created by staff. None of the universities claims a copyright in the work of staff (including teaching aids) and students.

\section{Directives essentials}

As shown by the survey mentioned above, one of the tasks of CTT should be the preparation of the directives concerning IP management of the parent university. In principle, all universities need to address the basic economic and legal issues of accounting for intellectual property within the directives - the means of inclusion in the asset, commercial value assessment method, commercial 
implementation, and control of revenues from commercial IP deployment. Another purpose of the directives is also to minimize potential conflict between the parties.

Internal directives should help to understand the entire decision-making process, responsible person's competency, and decision-making timeframe. Through internal directives, the duration of the different phases of IP protection can be set according to valid legislation. Directives should help employees to understand the entire intricate system of protection and application of IP in their institution. Therefore, it is essential to configure them specifically for each university, and to address fundamental issues according to processes and guidelines implemented by other universities, e.g. accounting system, classification of assets, division of funds, business rules, etc.

\section{Discussion}

The main objective of CTT activities is to build an organizational infrastructure and information database that allows for an effective management of technology transfer projects. At the end of this article, we try to describe the basic challenges faces by the CTT of the University of Žilina, encountered while setting the framework of the intellectual property protection and commercialization process.

The question is "How does the university acquire the intellectual property?" The answer to this question directly affects the method of accounting for intellectual property at the University and also the method of allocating credits, copyright or progenitor amount of rewards and direct costs associated with the protection of a specific type of IP.

Consequently, it is necessary to answer the following related questions:

1. How will the University use its intellectual property? If decided to commercialize the IP, on which market and under which conditions would it be realized? If not, is it possible to apply the IP into the training program or to present it at conferences or exhibitions?

2. Is it possible to modify or upgrade the solution, if the further developing or testing is necessary? The answer to this question also has a direct impact on the choice of method for commercialization and IP protection.

3. What are the financial aspects of the whole process of creation, protection and commercialization of IP? (This means costs associated with the creation, protection, retention of IP and income from its commercialization). The key aspect here is the interconnection to the accounting system of the entire university and proper adjustment of internal and external control mechanisms within the individual university departments and asset-related artificial persons.

Currently, it is still unclear how the results of research and development will be incorporated into the accounting aspect of our University. In practice, the University of Žilina uses methodological guidelines for accounting prototypes. At present, the CTT of the University of Žilina needs to address a serious question on how to charge for an IP, which is created as an output from research and development projects. Slovak legislation and reporting allow us to charge in the account 012Research and development costs - the intangible results of research and development, on intangible assets created by own development or in the course of its development, but only if it is possible to satisfy the following premises:

- the possibility of its technical completion, so that it can be utilized or commercialized,

- the intention of its completion, use or sale,

- the ability of the entity for use or sale, 
- the mean of generating future economic benefits and the existence of a market for the output of intangible asset or the intangible asset itself, or if it is used within the entity, its usability,

- the availability of adequate technical resources, financial resources and other resources to complete the development, use or sale,

- accurate costs valuation related to its acquisition during development.

In the accounts of intangible assets, however, we do not charge the cost of research, which was in the originally planned investigation carried out to acquire new scientific or technical knowledge (MF/24342/2007-74). Research costs are also accounted in the costs within those periods, which they incurred. Research costs mainly consist of activities aimed at: obtaining new knowledge; conducting the search, evaluating and selecting applications of research findings or other knowledge; searching for alternative materials, devices, products, processes, systems or services; and at the formulating, design, evaluation and final selection of possible alternatives for new or improved materials, devices, products, processes, systems or services.

It is often difficult to maintain a consistent and accurate decision because the development process can take several years. The whole system of research and development (R\&D) funding through projects requires accurate and complex monitoring of the use of allocated funds for various activities and persons. However, for internal usage, it is necessary to obtain discreet evidence that would allow accurate allocation of funding received directly from IP creation-related projects.

According to ZÚ (2002), it is possible to value the intangible assets created with own capacities, which is accounted for, at their own costs. Valuation at own costs for intangible assets represent direct costs incurred from production or other activities, and indirect costs related to production or other activities. Intangible assets are those items whose valuation is higher than 2,400 EUR with a utilization period longer than one year.

\section{Conclusion}

Intellectual property rights are currently perceived in the area of Higher Educational Institutions mainly through written articles, publications, and undergraduate, graduate or doctorate dissertations. Through the application of IP management of high quality, it would be possible to raise awareness on professional, legal and economic level for different types of IP at the university. In this article, we have briefly described one of the problematic issues encompassing the IP protection at our university. It is an ongoing challenge, which has a direct impact on all other phases of IP management and, therefore, should be incorporated into the internal documents of the University. In other words, it is necessary to incorporate the directives in the area of IP protection, technology transfer and knowledge with the whole internal processes of the University.

\section{Acknowledgement}

This research article is supported by the following project: University science park of the University of Žilina (ITMS: 26220220184) supported by the Research \& Development Operational Program funded by the European Regional Development Fund.

\section{References}

Babiaková, B. (2010). Využívanie výsledkov duševného vlastníctva na vysokých školách. Hodnota duševnej práce pre organizáciu a spoločnost' [Exploitation of the results of intellectual property at universities. The value of intellectual work for the organization and society]. Proceedings of the research grant VEGA no. 1/0865/08, 19-28. Pavol Jozef Safarik University in Košice. 
Bílá, A. (2010). Inovačná spolupráca technickej univerzity v Košiciach s hospodárskou a spoločenskou praxou [Innovative cooperation Technical University in Košice economic and social practice]. National and Regional Economics VIII, Technical University of Košice-Faculty of Economics. Herl'any, 51-59. Retrieved from http://www3.ekf.tuke.sk/konfera2010/ zbornik/files/konfera2010_zbornik.pdf

Brighton, D. (2012). Úloha smerníc v procese komercializácie technológií a poznatkov na univerzitách [The role of directives in the process of technology and knowledge commercialization at universities]. Transfer Magazine, 4, 8-11. Retrieved from http://www.stuscientific.sk/data/MediaLibrary/134/Transfer\%202012-2-medium.pdf

Griliches, Z. (1994). R\&D and Productivity-the econometric evidence. Chicago University Press.

Markman, G. D., Gianiodis, P. T., Phan, P. H., \& Balkin, D. B. (2005). Innovation speed: Transferring university technology to market. Research Policy, 34(7), 1058-1075. doi:10.1016/j.respol.2005.05.007

MF/24342/2007-74 (2007). Opatrenie Ministerstva financií Slovenskej republiky č. MF/24342/2007-74, ktorým sa ustanovujú podrobnosti o postupoch účtovania a účtovej osnove pre účtovné jednotky, ktoré nie sú založené alebo zriadené na účel podnikania [The Ministry of Finance of the Slovak Republic Measure no. MF/24342/2007-74, which stipulates detailed of the accounting procedures and the framework chart of accounts which are not based on or established for business purpose].

Siegel, D. S., Waldman, D. A., \& Link, A. N. (2003). Assessing the impact of organizational practices on the relative productivity of university technology transfer offices: an exploratory study. Research Policy, 32(1), 27-48.

Slovak Center of Scientific and Technical Information [CVTI] (2011). Základné koncepty, nástroje a prístupy k transferu technológií vo svete—prehl'adová štúdia [Basic concepts, tools and approaches to technology transfer in the world - overview study]. Bratislava. Retrieved from http://nitt.cvtisr.sk/buxus/docs/Studia_II_o_TT_

NITT_SK.pdf

Smernica 85 (2010). Smernica č. 85-Obeh účtovných dokladov v podmienkach Žilinskej univerzity v Žiline [Directive no. 85-Circulation of accounting documents in conditions of the University of Zilina]. Internal documentation of the University of Žilina (intranet).

Smernica 86 (2010). Smernica č. 86-Zásady obstarávania, evidovania a účtovania majetku v podmienkach Žilinskej univerzity v Žiline [Directive no. 86-Principles of procurement, registering and accounting of assets in conditions of the University of Zilina]. Internal documentation of the University of Žilina (intranet).

Smernica 98 (2011). Smernica č. 98-O postupoch pri verejnom obstarávaní v podmienkach Žilinskej univerzity v Žiline [Directive no. 98-The public procurement process in conditions of the University of Zilina]. Internal documentation of the University of Žilina (intranet).

ZVS (2002). Zákon č. 131/2002 Z. z. o vysokých školách a o zmene a doplnení niektorých zákonov [Act no. 131/2002 Coll. on universities and on amendment].

ZÚ (2002). Zákon č. 431/2002 Z. z. o účtovníctve a o zmene a doplnení niektorých zákonov [Act no. 431/2002 Coll. on Accounting as amended]. 